\title{
Identifying the determinants of electoral integrity and administration in advanced democracies: the case of Britain
}

\author{
ALISTAIR CLARK* \\ Politics, Newcastle University, UK
}

\begin{abstract}
Much discussion of electoral integrity focusses on new democracies. This paper explores the determinants of electoral integrity in a major established democracy in order to begin to identify drivers of electoral integrity for comparative scholars to exploit further. It does so through a novel measure of electoral administration in Britain which is brought together with comprehensive data on spending on electoral administration, whether concurrent elections were being held, size of electorate, number of constituencies administered, type of administration overseeing local electoral administration, and various socio-economic measures. The results establish a range of relationships to electoral integrity which will inform subsequent debates on election quality in other democracies, whether advanced or otherwise. In particular, the findings point to the importance of administrative resources in delivering electoral integrity in advanced democracies.
\end{abstract}

Keywords: electoral integrity; electoral administration; elections; British elections

\section{Introduction}

Understanding the integrity of the electoral process is a vital precursor for understanding any other aspect of electoral politics. Recognition of this point has led to the development of electoral integrity as a lively 'new agenda' in political science (Norris, 2013a). Much research in this area is often focussed upon democratizing countries, election observation missions, and the manipulation of elections in authoritarian regimes. In advanced democracies, the focus has remained largely on voting behaviour and party campaigns. This presupposes that the system for running elections permits free competition and choice, and is not biased or flawed for electors. This cannot be taken for granted; a range of recent difficulties in electoral processes in advanced democracies have highlighted the need for an examination of electoral integrity in such contexts (Wise, 2001; Alvarez and Hall, 2006; James, 2012; Clark, 2015). In particular, it is important to establish variance in the integrity of the electoral process, and to understand what factors may drive or impede the delivery of high-quality elections in such democracies.

This paper's major contribution is to present a multivariate analysis of various aspects which might impact on election quality in advanced democracies.

* E-mail: alistair.clark@ncl.ac.uk 
It approaches this through an index of election administration derived from election administrators' performance standards in the 2010 British general election. The index is brought together with a range of contextual data, including electoral, geographical, and socio-economic variables, to provide an exploratory analysis of which factors may be more or less important in driving election quality in advanced democracies. Britain is typical of several advanced democracies, notably the United States but also smaller democracies like Ireland, in that local electoral officials have the main responsibility for delivering elections. Even where central government oversees elections, there is often still a sizeable role for local government in delivering those elections. Consequently, considerable variation in standards of electoral administration can exist. Britain is therefore an excellent case study for building both theory and knowledge about the relationship between electoral integrity and its determinants. Such a multivariate analysis in an advanced democracy during a national parliamentary general election is extremely rare. The findings are important because evidence from such a case can be utilized comparatively to interrogate these issues in other advanced democracies.

This paper proceeds as follows. The first section introduces the broad concept of electoral integrity, before focussing more narrowly on the crucial aspect of electoral administration and its contribution to election quality. The second section discusses some potential contextual issues that may impact on the provision of high-quality elections. These include, for example, the size of the electorate, a number of electoral structure variables, the amount spent on electoral administration, and institutional and socio-economic variables. A number of hypotheses are derived from these ideas. The third section introduces the data utilized in this study, while the fourth section analyses these data. The conclusion reflects on the implications of these findings.

\section{Electoral integrity and electoral administration}

The integrity of the electoral process and the potential for manipulation or malpractice to occur has long been a concern for policymakers and politicians. Scholars are now catching up with such questions and how they might affect electoral choice and competition (Birch, 2011; Norris, 2014; Norris et al., 2014). Students of democratization and electoral autocracies have, to date, taken these questions most seriously. In potentially high-conflict political situations, the integrity, fairness, and transparency of the process can all be disputed and have the potential to lead to, at best, manipulations of political behaviour, or at worst, challenges to the legitimacy of results and widespread violence (Birch, 2011; Norris, 2014). In contrast, in advanced democracies with long experience of running elections, the quality of the electoral process has tended to be taken for granted. This largely remains the case, despite an upsurge of interest in the operation of electoral processes in the United States in the aftermath of the controversial 2000 Bush-Gore presidential election (Wise, 2001; Montjoy, 2008; Hasen, 2012). Evidence from elsewhere is sporadic, 
with the other major advanced democracy receiving any sustained, albeit limited, levels of attention being Britain (Wilks-Heeg, 2009; James, 2012, 2013; Norris, 2014: 5, 32; Clark, 2014a, 2015).

Electoral integrity can be approached from either a broad or more narrowly defined perspective. Having universal suffrage and free, competitive, and fair elections is a minimal requirement and essential component of the quality of democracy (Morlino, 2004). Consequently, recent accounts define electoral integrity as being rooted in 'international conventions and global norms, applying universally to all countries worldwide throughout the electoral cycle, including during the pre-electoral period, the campaign, on polling day and on its aftermath' (Norris, $2013 a, b)$. Such norms emphasize fundamental freedoms, democracy promotion, and human rights, without which elections cannot be classified as 'free and fair'.

A distinction can be made between first and second-order integrity issues (Vickery and Shein, 2012; Norris, 2013a). First-order issues revolve around violations of these generally accepted freedoms, which may end in political violence. Second-order malpractices 'characteristically involve more mundane issues of maladministration, lack of technical capacity or human error' (Norris, 2013a: 566). The argument is that electoral integrity requires both sets of issues to be present, but that second-order issues are not enough, on their own, to provide integrity (Norris, 2014: 36).

An important difficulty with this distinction is that it is often these narrower 'second-order' administrative issues which can give political actors the excuse to claim electoral fraud, bring democratic processes into disrepute, and ultimately lead to controversial outcomes, whether through violent or other means (Minnite, 2010). The notion of these being mundane administrative 'second-order' malpractices appears to downplay this.

Exploring linkages between integrity in public affairs and public administration, Evans (2012) argues that integrity is evident where governance has stable governing parameters, accountability, transparency, competence, anti-corruption measures, and a focus on public value. These are all delivered through administrative processes. In democracies, the administration of the electoral process delivers the public good of elections held under universal suffrage. It also sets the various parameters by which elections are run, such as the legal framework for conducting elections, accountability, and transparency mechanisms such as independent observation, and enforcement measures in case of disputes (ACE Electoral Knowledge Network, n.d.). Indeed, Elklit (1999) shows how the effective implementation of electoral administrative processes, throughout the electoral cycle, can play a crucial role in delivering high-quality elections. More generally, poor performance in electoral administration can lead to a range of negative consequences such as disenfranchisement, skewed electoral outcomes, and electoral violence. It can also impact negatively on confidence in the democratic process (Atkeson and Saunders, 2007). While electoral integrity may, more broadly, consist of global norms, whether in democratizing countries or advanced democracies, it 
cannot therefore exist without fair, transparent, inclusive, and equitable election administration which provides an effective and reliable aggregation of the vote (Schaffer, 2008; Birch, 2011; ACE Electoral Knowledge Network, n.d.).

Running elections for a mass electorate is highly complex. Demands on electoral administrators are often intense, but also intermittent, with many aspects having to be organized to extremely tight timescales. For a national election, manifold logistical and organizational tasks must be undertaken with minimal difficulties to run the contest effectively. Administrators must comply with electoral legislation, recruit, train, and manage large numbers of staff, many of which are non-specialists only employed for the short-term conduct of the election, and also ensure that an accurate electoral register is compiled. Polling stations must also be located and equipped properly. Finally, when polls close, the counting and tabulation process must take place securely and transparently.

Potential difficulties abound. Alvarez and Hall (2006) note principal-agent problems in running elections. Mozaffar and Schedler (2002) highlight tensions between administrative efficiency, political neutrality, and public accountability that election administrators must seek to balance. Others have suggested that the complexity of elections make them prone to what might be termed 'normal accidents', the propensity for complexity, and pressure to deliver leading to errors in implementation each of which may, on their own, be relatively small but can multiply into a much bigger issue (Perrow, 1999; Montjoy, 2008). While this might appear to require central co-ordination and planning, in most advanced democracies, voting is, of necessity, something that occurs in voters' local areas. Integrity, therefore, also depends on how elections are locally implemented. Poll workers in local areas administering elections can thus be seen as 'street-level bureaucrats' (Kimball and Kropf, 2006; Clark and James, 2015). Consequently, localized standards can vary considerably, rendering perceptions of the electoral process as, at best, not uniform, and, at worst, threatening the entire credibility of the process (Atkeson and Saunders, 2007; Hall et al., 2007; Dahlberg and Holmberg, 2014).

A number of checklists have been proposed to allow an assessment of electoral administration. Elklit and Reynolds $(2001,2005)$ highlight 12 steps in the electoral process and, in their different versions, subdivide these steps into between 47 and 54 different variables for observers to assess. ${ }^{1}$ For instance, in relation to voter registration, their steps include assessing the ease of registration for voters, the freedom from any bias in the franchise, mechanisms for auditing the register and ensuring public confidence, and that these processes comply with international standards. Essential, important, and desirable characteristics of electoral integrity are all given weightings according to their importance in their schema. Pastor (1999) offers a framework with pre-election, election, and post-election phases with 22 indicators in total for application to developing countries. Mozaffar and Schedler (2002)

\footnotetext{
${ }^{1}$ See also Norris (2014, appendix B).
} 
provide a threefold categorization of rule-making (i.e. the rules of electoral competition and governance), rule application (i.e. organizing the election process), and rule adjudication (certifying results and resolving disputes).

Implicit in many of these frameworks is the idea that the administrative aspects of electoral integrity can be combined to provide an overall assessment of a set of elections. For example, Elklit (1999: 37) talks of a combined election quality measurement where states can record high or low scores. Similarly, Norris (2014: 32-33, 66) discusses how continuous measures can be applied to assess all types of democracies, including those with extensive experience of conducting elections. From an advanced democracy perspective, the utility of such an approach has been strongly advocated by Gerken (2009). She argues that too little is known about the state of electoral administration and its consequences, whether good or bad, with much data either often difficult to collect or simply unknown. Gerken's solution is a 'democracy index' which focusses on the administrative issues of registration, balloting, and counting. It would provide potentially both a national-level assessment, and one which highlights variation between states and localities. Elklit and Reynolds (2005: 155-156) highlight the utility of such an approach for cross-national comparisons and for different types of democracies. Such variation could be used to highlight best practice and to improve electoral processes in localities or countries showing substantial variation from this. Moreover, a democracy index would provide incentives which encourage the improvement of electoral administration.

\section{Influences on the quality of electoral administration}

If the aim of such an index is to measure variation in election quality in advanced democracies, what factors may determine or be associated with higher or lower levels of performance in election administration? Despite the numerous frameworks described above, analysts have little empirical evidence on what may drive higher levels of performance in election administration in advanced democracies. ${ }^{2}$ A number of determinants can nevertheless be suggested.

The first group of determinants relate to the electoral structure of the local area the election is being administered in. Three things might conceivably impact upon the quality of electoral administration in this regard. First, the size and concentration of the electorate being administered is important, with larger electorates arguably adding more pressures on electoral administrators, and smaller electorates easier to manage. Second, in many countries, elections to different levels of government are held concurrently. This certainly complicates things for political parties (Clark, 2012). It is also likely to add to pressures on administrators, to the detriment of election quality. Third, in a number of electoral systems such as single

\footnotetext{
2 Although some evidence about the broader concept of electoral integrity, described earlier in this article, in advanced democracies is beginning to be collected (see Norris 2014).
} 
member plurality and mixed-member proportional, electoral administrators may be running more than one geographical constituency or area. Doing so is likely to add further complications for administrators and as a consequence, this may lead to lower levels of performance.

These electoral structure ideas provide a number of hypotheses that can be tested against an index of election administration. These are as follows:

HYPOTHESIS 1: Electoral management performance improves when smaller local electorates are being administered.

HYPOTHESIS 2: Electoral management performance improves when only one type of election is being administered.

HYPOTHESIS 3: Electoral management performance improves when only one constituency or local area is being administered.

Electoral administrative performance is influenced by its relationship with the broader environment of public administration within which it operates (Hale and Slaton, 2008). The second group of factors that may influence performance on any index of electoral administration therefore relate to what might be termed organizational or institutional factors. These issues involve the administrative form the local authority administering the elections takes, the party political composition of the council, or the level of resources that local authorities employ on election administration. First, practitioner analyses suggest that the type of local authority administering the elections can be associated with differential levels of performance on different aspects of election administration (Electoral Commission, 2009b, 2010a, b; Rosenblatt et al., 2012; Snelling, 2015). However, taking a broader public administration approach, Murphy et al. (2011) tested for differences between different types of local authorities on a performance assessment regime attempting to measure the Comprehensive Performance Assessment (CPA) of English local government between 2002 and 2009. They found little difference between different types of authority, arguing that variation occurred as much between as within different types of local government structures. These contradictory findings therefore suggest that establishing whether or not the institutional type of local authority may have an impact on electoral management performance is important.

The partisan composition of the local authority has been shown to have a potential impact upon local public policy outputs and local authority capacity (Andrews and Boyne, 2011). Consequently, partisan composition may also impact upon performance on electoral administration capacity, due to choices made by local authorities. Certain parties may place more emphasis on electoral administration than others, with potential partisan effects. Thus, American electoral administration has been criticized for its partisan nature, and the impact of this upon electoral processes (Kimball and Kropf, 2006). The general perception is that broadly liberal or left-leaning parties are more concerned with using electoral 
administration to widen participation, while right-leaning parties are more restrictive (Kimball and Kropf, 2006; Hasen, 2012). This requires qualification in some contexts. Returning officers (ROs) running and administering elections in British local government are non-partisan civil servants. They are expected to perform their duties impartially without heed to partisan loyalties. However, the partisan make-up of the local authority may still be relevant because the governing party or parties are in a position to decide priorities and can, should they choose, put a greater or lesser emphasis on the provision of electoral services.

Third, the question of resources is often highlighted as crucial, albeit in a negative way. Birch (2011: 26) suggests a link between electoral mispractice which evolves from a lack of resources in her comparative study. Pastor (1999) argues that in developing countries, a causal chain links weak spending on public administration and poor performance in electoral processes. This argument has also been made in advanced democracies. Hall and Tokaji (2007) and Gerken (2009: 118) both suggest that electoral administration in the United States is inadequately financed. The Chair of the UK Electoral Commission similarly notes inconsistencies throughout the United Kingdom in the amount available to fund electoral administration, indicating that this impacts upon the service received by voters on polling day (Wilks-Heeg, 2009; Watson, 2011: 139; James, 2013). Increasing demands from new legislation, technology, and practices all stretch scarce finances and resources for electoral administration even further (Montjoy, 2010). Mostly, these arguments are based on assertion, but, in a rare data-driven analysis, Clark (2014a) suggests that there is a positive relationship between spending on election administration and higher levels of performance in electoral management.

These institutional and organizational issues provide further hypotheses that can be tested against an index of electoral administration. These are as follows:

HYPOTHESIS 4: Differences in institutional type of local authority will impact independently on electoral management performance.

HYPOTHESIS 5: Electoral management performance is positively related to the proportion of seats held by liberal/centre-left parties on the local authority.

HYPOTHESIS 6: Electoral management performance improves with more spending on electoral administration.

The final issue that might be examined is whether any potential influences may be exogenous in nature. Andrews et al. (2005) found that poor performance in the local authority CPA was significantly influenced by exogenous factors such as social structure. This can be applied to electoral administration; socio-demographics are regularly associated with problems of electoral registration, particularly with mobile or 'hard-to-reach' groups such as students, immigrants, and the less well-off (Rosenblatt et al., 2012; James, 2014). The Electoral Commission (2010a, b), for instance, associated lower rates of registration with cities with large student 
populations, population movement, and deprivation. Local activities are a central tool in reaching these groups (Snelling, 2015). These ideas provide a final hypothesis:

HYPOTHESIS 7: There is a negative relationship between demographic groups who are hard to reach and higher levels of performance in election quality.

\section{Electoral integrity in Britain}

Insights into these broad theoretical questions can be provided by examining the performance of British electoral administrators. Britain is an excellent case for doing so. Like a number of advanced democracies, British elections are administered by local authorities who have discretion, within statutory requirements, in determining how elections are implemented. This is the case also in both the United States and Canada, as well as smaller democracies such as Ireland (James, 2012; OSCE/ODIHR, 2015). Even where a national government body is responsible overall for election conduct, local authorities can have considerable responsibilities. For example, Italy's Interior Ministry has overall responsibility, but the actual process is delivered via district and regional election offices alongside more than 81,000 municipal election offices. Observation reports show clear variation at this local level (OSCE/ODIHR, 2008, 2013). Similarly, German elections are delivered via a structure which reaches down to the local electoral district and precinct (Breunig and Goerres, 2011), French local government is responsible for running polling stations, electoral administration, and registration (Norris, 2015: 118), and Australian elections are delivered through divisional offices responsible for each electoral division. ${ }^{3}$ As Norris (2015: 23-24) observes, in both nationally organized and also decentralized systems of electoral governance, there is a sizeable role for local authorities in delivering elections. As a consequence, there will also be variation in practice and delivery which needs to be explained.

Given the dearth of data available to assess and test issues of electoral integrity in advanced democracies, and the ubiquity of local authorities in delivering elections in those democracies, findings from a British general election are potentially generalizable across advanced democracies, and may also inform debates in democratizing countries.

Although British electoral administration has largely been taken for granted, two factors have recently changed this. First, a number of high-profile difficulties in election administration in recent years have highlighted both the fragile nature of election quality in some places, and, as a consequence, underlined variation in practices across Britain. Examples include voters being turned away from some

\footnotetext{
${ }^{3}$ For Australia, see the Australian Electoral Commission webpage 'AEC Organisational Structure': http://www.aec.gov.au/about_aec/structure.htm (27 October 2015).
} 
polling stations in a number of cities in the 2010 general election, an extraordinarily large number of invalid ballots in the 2007 Scottish elections, and in 2005, an election court judge likening the conduct and administration of postal voting in local elections in Birmingham to that of 'a Banana Republic' (Stewart, 2006; Denver et al., 2009; Wilks-Heeg, 2009; James, 2010; Clark, 2015). Indeed, it is often local elections which have proved most problematic in Britain, attracting many allegations of electoral mispractice (Wilks-Heeg, 2009; Sobolewska et al., 2015: 11). The toughest test for election administrators is, nevertheless, a national general election. Watson (2011: 129) observes that nearly 24 million votes were cast in around 40,000 polling stations in the 2010 general election, with 5.8 million postal votes also being cast. A further 13.6 million votes were also cast in local elections in parts of England on the same day in 2010.

Second, since the Political Parties, Elections and Referendums Act 2000, the United Kingdom has had an Electoral Commission responsible for overseeing numerous aspects of the electoral process. This reports to parliament, but operates independently. As part of the Commission's work, increasing amounts of information about the conduct of electoral politics have become publicly available. The Electoral Commission was given the role of overseeing both election process spending and setting performance standards in the Electoral Administration Act 2006. Their data now therefore include information on both performance standards for ROs and electoral registration officers (EROs). Electoral Commission data also include spending on electoral administration. Nevertheless, the delivery of electoral administration in Britain ultimately remains the responsibility of local government. The Electoral Commission has currently no formal powers of direction over the local ROs and EROs, who are ultimately responsible for delivering the elections. Consequently, there are inevitable variations in both practice and performance in delivering electoral administration which need to be explained (Clark, 2014a, 2015).

\section{Data and approach}

Data for this study are drawn from a range of sources. The key source providing evidence of variation in practice amongst electoral administrators is a survey of performance standards for ROs in the 2010 British general election. ROs are non-partisan, civil servants responsible for the conduct of elections in their local authority area. Data on performance standards were based on self-completed surveys of ROs collected by the Electoral Commission in the aftermath of the election. ${ }^{4}$ This survey had a high response rate of 372 out of 379 local council ROs who were responsible for running the 2010 general election in the 632

\footnotetext{
${ }^{4}$ Complete spreadsheets with RO data are available from http://www.electoralcommission.org.uk/ find-information-by-subject/performance-standards/performance-in-running-elections-and-referendums (15 November 2013).
} 
constituencies in Great Britain. In other words, the analysis is undertaken at the level of these local authority ROs, and based on a response rate of $98 \% .^{5}$

It is, of course, possible to raise questions about the use of self-completed questionnaires to measure performance standards in public administration. Concerns about public administrators seeking to 'game' the outcomes of such standards have been evident in the wider literature (Heckman et al., 1997; Heinrich, 2002). Indeed, the Organisation for Security and Co-operation in Europe's (OSCE) election observation report on the British general election in 2010 highlighted concern at such self-completion (Organisation for Security and Co-operation in Europe/Office for Democratic Institutions and Human Rights, 2010).

This notwithstanding, ROs are ideal respondents. They are senior electoral administrators responsible for delivering elections to all levels of institution, from local government to the European parliament, to at least statutory requirements. They can therefore be considered expert practitioners in electoral administration. The use of surveys with such expert respondents has become widespread in political science. The reliability of such surveys has been considered at length, including in the field of electoral integrity (Steenbergen and Marks, 2007; Norris, 2014; Coma and van Ham, 2015). While acknowledging the necessary caveats, findings have underlined the ability of experts to judge aspects of elections. Responses to the performance standards survey were also audited by the UK Electoral Commission, albeit on a sampled basis (Electoral Commission, 2010a). If ROs were systematically overstating performance, it might be expected that there would be little variation in responses. As the analysis below shows, variation is clearly evident. Combined, this means that the 2010 RO performance standards results are relatively reliable indicators of electoral administrative performance.

These performance standards were used to report on performance in both the 2009 European and 2010 general elections (Electoral Commission, 2009b, 2010a). They revolve around three broad areas, from which seven measureable standards were derived. They are outlined in Table $1 .^{6}$

The various frameworks described above tend to use ordinal scales to rate particular aspects of election quality (see Norris, 2014: Ch. 3). Elklit and Reynolds (2005), for example, adopt a four-point Likert scale to rank their variables of interest. The Electoral Commission adopt a similar approach, utilizing a three-point ordinal scale of not meeting the standard, meeting the standard, and above the standard. In each performance standard, a range of criteria are specified that the RO must comply with. Thus, under performance standard 2 on planning processes, to fail to meet the standard ROs would have no written formal plan, relying instead on experience and informal interactions. To meet the standard, the RO would have a

\footnotetext{
5 This excludes the 18 constituencies in Northern Ireland which is exempt from these performance standards and has different arrangements with the province-wide Electoral Office of Northern Ireland responsible for administering most elections there.

${ }^{6}$ Integrity is used in a much narrower way in the Electoral Commission standards than in academic usage discussed in this article, referring in the performance standards to the accurate counting of eligible votes.
} 
Table 1. Performance standards for returning officers in the 2010 general election

\begin{tabular}{ll}
\hline \hline Subject & Performance standard \\
\hline Planning and organization & 1. Skills and knowledge of returning officer \\
& 2. Planning processes in place for an election \\
& 3. Training \\
Integrity & 4. Maintaining the integrity of an election \\
Participation & 5. Planning and delivering public awareness activity \\
& 6. Accessibility of information to electors \\
& 7. Communication of information to candidates and agents \\
\hline \hline
\end{tabular}

Source: Electoral Commission (2009a, 2010a: 2).

Table 2. Performance standards in the 2010 general election (\%)

\begin{tabular}{lcccc}
\hline \hline & Not meeting standard & Meeting standard & Above standard & $N$ \\
\hline Skills and knowledge & 1.9 & 73.9 & 24.2 & 372 \\
Planning processes & 2.2 & 53.8 & 44.1 & 372 \\
Training & 1.6 & 68.0 & 30.4 & 372 \\
Integrity & 5.6 & 83.6 & 10.8 & 372 \\
Public awareness activity & 3.2 & 67.5 & 29.3 & 372 \\
Accessibility of information to electors & 8.1 & 79.0 & 12.9 & 372 \\
Communication to candidates and agents & 0.3 & 54.4 & 45.3 & 371 \\
\hline \hline
\end{tabular}

Source: Electoral Commission (http://www.electoralcommission.org.uk).

formal written plan which includes overall objectives, a risk register, staffing and organizing venues for polling stations and the count, and any contracts for outsourced material (e.g. printing ballot papers) to be in place. To be above the standard, the RO has worked with external bodies (e.g. local media, community groups, and other interested electoral officers) to develop their plans, and have an evaluation methodology to establish its effectiveness (Electoral Commission, 2009a). ${ }^{7}$ Performance on each of the individual standards is outlined in Table 2.

As Norris (2014: 66) observes, continuous or interval-level measures are preferable to ordinal ones in attempting to measure election quality. The dependent variable utilized in this study is therefore an index of election administration. This is derived from RO performance standards results reported in the 2010 general election, and inspired by debates around indexing election quality mentioned above. It is an additive index, created by summing the scores achieved by ROs on each of the seven performance standards, with values of 1 given to not meeting the standard, 2 given to meeting the standard, and 3 given where ROs were above the standard. The resulting index therefore potentially varies between a minimum score

\footnotetext{
${ }^{7}$ For the full list of criteria for each standard, see Electoral Commission (2009a).
} 
of 7 and a maximum of 21. Reliability analysis achieved a Cronbach's $\alpha$ score of 0.765. This indicates that these standards are suitable for index construction (Pennings et al., 1999: 96-97). ${ }^{8}$

It is worth noting that the Electoral Commission declined the opportunity to create such an overall index, claiming that this would 'maintain transparency and simplicity ... aggregating the total number of standards not met, met or exceeded across all seven standards may not give an accurate picture of performance' (Electoral Commission, 2009b: 8). Nevertheless, such an aggregate approach has been utilized in relation to performance standards data before in British local government, notably the 2002-09 CPA (Andrews et al., 2005). Such an approach is therefore accepted in assessing public administration in Britain.

Consideration was given to weighting these standards. However, deficiencies in any aspect can cause complications and difficulties with the electoral process. Many difficulties can be attributed to poor planning, while accessibility of information to electors would seem to be crucial for voters to be well informed about the process. Indeed, Elklit (1999) makes this point by arguing that, if polling day is to run smoothly, it is pre-election administration that is arguably crucial in leading to high-quality elections. In the absence of any accepted weighting standard, the approach adopted here has weighted each aspect equally.

The index offers an important advance on what is currently known in three ways. It provides more variation than permitted by the performance standards as originally reported. It permits an overall view of electoral administration to be obtained, while also enabling easier comparison of standards between different types of local government and areas within Britain than hitherto possible. Crucially, this provides an indicator against which potential drivers of performance can be assessed.

A number of indicators are utilized as independent variables. Three electoral structure variables are deployed. First, electorate density is a proxy variable for the size and concentration of the electorate served by each local authority. This is based on a ratio of the number of electors in the area administered divided by the local authority size in hectares and calculated from the electorate and hectare data in the Electoral Commission's electoral costs data. Second, whether the local authority was administering local elections concurrently with the general election is assessed by a simple yes/no indicator (coded as a dummy variable $1-0) .{ }^{9}$ Finally, whether ROs were responsible for multiple constituencies is also measured by use of a dichotomous yes/no variable (also coded $1-0) .{ }^{10}$

${ }^{8}$ Pennings et al. (1999: 96-97) note that a Cronbach's $\alpha$ score of 0.7 or over means that the component indicators of such an index are suitable and that creating an index from such variables 'adds to the discriminating power of the theoretical concept'.

9 Data on concurrent elections was taken from the Guardian's summary of the 2010 local elections, available at http://www.theguardian.com/society/table/2010/may/07/local-elections (22 November 2013).

${ }^{10}$ While a council's boundaries may overlap several constituencies, it is not necessarily the case that that council's RO administers each of those constituencies as they may be run by neighbouring councils. It is often far from clear from council websites which constituencies they are responsible for administering where 
Three sets of independent variables are utilized for institutional and resource issues. There are a range of different council types in Britain: Scottish and Welsh unitary councils, London boroughs, unitary county, unitary district, metropolitan district, and two-tier district councils. These are represented by dummy variables for each different type of council administration. Partisanship on the local authority is measured by the proportion of seats on the local authority held by Labour and the Liberal Democrats at the immediate round of elections before $2010 .{ }^{11}$ Both parties have shown concern with electoral administration. Labour in office sought to change a range of electoral practices to increase turnout (James, 2010), while issues of electoral reform have long been a Liberal Democrat concern. ${ }^{12}$ Local authority level data on spending on election administration in 2010-11, which covers the period of the 2010 general election, are deployed as a proxy variable for the resources election administrators can bring to bear on running the election, calculated as spending per elector. This is a composite variable of the total amount spent by local authorities on electoral registration in the period, combined with the total amount spent on the actual practicalities of running the election, divided by the local authority electorate. These electoral spending data are drawn from the Electoral Commission's Financial Information Survey, which was designed to collect information on the financing of elections across Britain. This was a full population survey of local authority election administrators with a high response rate $(82.8 \% ; N=378) .^{13}$

The final group of independent variables are essentially socio-demographic and geographical in nature. The effect of transient or migratory 'hard-to-reach' populations is measured by two variables: the level of internal migration (i.e. within the United Kingdom) experienced by that local authority in 2010; and the proportion of students in the local authority area. Final variables utilized as proxies for hard-to-reach populations are the proportion of long-term unemployed, never worked, and routine workers in the local authority area. With the exception of internal migration, which is an estimate from the Office of National Statistics, these measures are based on Census 2001 data measured at the level of the local authority. ${ }^{14}$

this is the case, as they often report the results for all the constituencies their residents may have parliamentary representation in. In the absence of precise numbers, this variable is a simple indicator of whether they are likely to be responsible for multiple constituencies or not. The author is grateful to Phil Thompson and Gemma Rosenblatt of the Electoral Commission for providing data in this regard for English councils. Data for Scottish and Welsh councils were estimated from their websites by the author.

${ }^{11}$ Data for this were drawn from local election briefing papers between 2007 and 2010 produced by the House of Commons Library, available at http://researchbriefings.parliament.uk/ (10 June 2015).

${ }^{12}$ For example, the Twitter feed @UKElectionLaw is run by a high-profile Liberal Democrat activist.

13 These data are available in Excel spreadsheet form from the Electoral Commission at http://www. electoralcommission.org.uk/find-information-by-subject/performance-standards/financial-information (9 April 2014).

${ }^{14}$ Internal migration data are from 'Internal Migration by Local Authorities in England and Wales mid2010', available at http://www.ons.gov.uk (23 February 2015) and for Scotland from 'Local Area 
Table 3. Descriptive statistics

\begin{tabular}{lccc}
\hline \hline Interval variables & Mean & Minimum & Maximum \\
\hline Integrity index & 15.8 & 11 & 21 \\
Electorate density & 10.62 & 0.07 & 97.77 \\
EA spending ( $£$ per elector) & 4.38 & 1.17 & 10.69 \\
Partisanship (combined \% seats for Labour and Liberal Democrats) & 41.65 & 0 & 100 \\
Internal migration ('000s) & 0.1 & -8.8 & 8.1 \\
Students (\%) & 6.38 & 3.42 & 25.59 \\
Long-term unemployed (\%) & 0.93 & 0.22 & 2.40 \\
Never worked (\%) & 2.29 & 0.74 & 11.63 \\
Routine workers (\%) & 9.23 & 2.26 & 18.58 \\
Other variables & & & \\
\hline Concurrent local elections & & & \\
Multiple constituencies & & 163 & \\
Two-tier district councils & & 154 & \\
Unitary districts & & 197 & \\
London borough & & 44 & \\
Unitary county & & 32 & \\
Metropolitan districts & & 9 & \\
Scottish unitaries & & 36 & \\
Welsh unitaries & & 22 & \\
\hline \hline
\end{tabular}

\section{Analysis}

As Table 3 demonstrates, scores on the index vary between 11 at the lower end of performance and the maximum score possible of 21 at the top end of performance. The mean score on the index was 15.8 , with a standard deviation of 2.2. This means that most ROs score somewhere between 13.6 and 17.9 on the index. In total, 38 ROs fall outside the standard deviation score at the bottom end of the index, while 82 ROs fall outside it at the top end of the index with 11 ROs achieving the maximum score of 21 . In other words, more than half of ROs (191 or $51.3 \%$ ) are located below the mean on the integrity index, while the remaining 180 or $48.7 \%$ perform above average. The modal value on the index is 14 , with a median of 15 . There is a slight positive skew of 0.489 in the index, but this does not appear to be serious. Consequently, the results can effectively be taken as a normal distribution and suitable for subsequent analysis (Andersen, 2004). Table 3 also presents the descriptive statistics for the independent variables utilized in the analysis.

Statistically significant bivariate relationships are evident between the electoral administration index and some of the independent variables. Taking the electoral structure variables first, responsibility for multiple constituencies seemed to have an impact in 2010. Around 154 ROs ran multiple constituencies and they recorded a

Migration 2012' which contains data from 2006 to 2012, available at http://www.gro-scotland.gov.uk/ statistics/theme/migration/mig-stats/local-area-reports.html (23 February 2015). 
mean of 16.2 on the index, compared with a mean of 15.5 for those only running one constituency. This difference was statistically significant at the $P<0.01$ level. The other electoral structure variables did not have a statistically significant relationship to the integrity index.

With the organizational and resourcing variables, type of local administration seemed to make a difference. There is evident variation of performance between the different types of local authority. This ranges from a score of 16.7 for Scottish unitary councils at the high end of performance to 15.4 for two-tier district councils at the bottom end. While strength of association is not strong, with an $\eta$ value of just 0.205 , results assessing types of local authority were statistically significant at the $P<0.05$ level. This suggests that differences between council types may be systematic. Spending on election administration per elector also appeared to make a difference. Bivariate analysis returned a positive Pearson's correlation of 0.160 which was statistically significant at the $P<0.01$ level, thereby underlining the view that more spending on election administration improves election quality. There is however no statistically significant bivariate relationship with partisanship. Finally, none of the demographic or socio-economic variables had a statistically significant relationship to the integrity index, although the proportion of those who have never worked came close to 0.055 .

Table 4 presents three exploratory ordinary least squares (OLS) multiple regression models which begin to tease out which variables may be most important, while at the same time controlling for others. ${ }^{15}$ Model 1 examines the electoral structure, with electoral density, and dummy variables included for concurrent elections and multiple constituencies. Model 2 adds institutional and resource issues in the form of council type, partisanship, and the amount spent on election administration per elector to the analysis, with dummy variables representing the various different council types administering elections in Britain. ${ }^{16}$ Model 3 adds socio-economic variables to the electoral structure and some institutional variables. Because of the relatively low $N$, statistical significance is also tested for at the slightly more relaxed level of $P<0.1$ in addition to the standard $P<0.01$ and $P<0.05$ levels.

Model 1 initially appears to highlight the importance of the electoral structure of the area that the RO is administering to levels of electoral integrity in the locality. Electorate density has no independent statistically significant impact, thereby suggesting that electorate size is not necessarily a driver of election quality and

\footnotetext{
${ }^{15}$ It is recognized that treating the dependent variable as an interval variable for OLS regression when it is essentially an ordinal 15-point scale may not be ideal. Nevertheless, the practice of using OLS under such conditions is widespread and accepted, under certain conditions, in the quantitative and research literature (Andersen, 2004; Andrews et al., 2005). For the preliminary analysis at hand it is therefore appropriate, not least as the aim is an exploratory determination of the nature of relationships between various variables and election quality. The regressions were also run with missing values replaced by the mean to increase the $N$ available for analysis. These analyses are not reported here due to space considerations, but broadly corroborate the findings.

16 The reference category for council type is two-tier districts.
} 
Table 4. OLS regression on British electoral administration index 2010

\begin{tabular}{|c|c|c|c|c|c|c|c|c|c|}
\hline \multirow[b]{2}{*}{ Variables } & \multicolumn{3}{|c|}{ Model 1} & \multicolumn{3}{|c|}{ Model 2} & \multicolumn{3}{|c|}{ Model 3} \\
\hline & $b$ & SE & $\beta$ & $b$ & SE & $\beta$ & $b$ & SE & $\beta$ \\
\hline Constant & 15.588 & 0.167 & & 14.724 & 0.461 & & 14.149 & 0.765 & \\
\hline Electorate density & 0.007 & 0.009 & 0.046 & -0.002 & 0.014 & -0.014 & -0.005 & 0.013 & -0.038 \\
\hline Multiple constituencies & 0.714 & 0.243 & $0.162 * * *$ & 0.670 & 0.343 & $0.156^{*}$ & 0.917 & 0.276 & $0.213 * * *$ \\
\hline Concurrent elections & -0.466 & 0.255 & $-0.107^{*}$ & -0.543 & 0.321 & $-0.126^{*}$ & -0.573 & 0.290 & $-0.133 * *$ \\
\hline EA spending ( $£$ per elector $)$ & & & & 0.238 & 0.093 & $0.169 * *$ & 0.256 & 0.086 & $0.182 * * *$ \\
\hline Partisanship & & & & -0.007 & 0.006 & -0.080 & -0.009 & 0.007 & -0.099 \\
\hline Unitary districts & & & & 0.253 & 0.437 & 0.041 & & & \\
\hline London borough & & & & 0.588 & 0.737 & 0.079 & & & \\
\hline Unitary county & & & & -0.007 & 0.876 & 0.000 & & & \\
\hline Metropolitan districts & & & & 0.891 & 0.574 & 0.120 & & & \\
\hline Scottish unitary & & & & 0.801 & 0.481 & $0.111 *$ & & & \\
\hline Welsh unitary & & & & 0.207 & 0.601 & 0.022 & & & \\
\hline Internal migration & & & & & & & 0.002 & 0.134 & 0.001 \\
\hline Routine (\%) & & & & & & & 0.058 & 0.061 & 0.073 \\
\hline Never worked (\%) & & & & & & & 0.325 & 0.164 & $0.215^{* *}$ \\
\hline Long-term unemployed (\%) & & & & & & & -0.755 & 0.435 & $-0.169 *$ \\
\hline FT students (\%) & & & & & & & 0.030 & 0.052 & 0.040 \\
\hline$R^{2}$ & & 0.034 & & & 0.096 & & & 0.097 & \\
\hline$N$ & & 370 & & & 297 & & & 295 & \\
\hline
\end{tabular}

$b=$ Unstandardized regression coefficients; $\beta=$ standardized regression coefficients.

$* * * * *$ S Statistically significant at $0.01,0.05$, and 0.1 levels, respectively.

permitting the rejection of Hypothesis 1. Instead, and contrary to the bivariate analysis, both concurrent elections and running multiple constituencies have statistically significant relationships with the integrity index. The analysis suggests that Hypothesis 2 can be confirmed. Running concurrent elections led to lower levels of performance on the index in 2010, a relationship which is statistically significant, albeit at the slightly lower level of significance of $0.1{ }^{17}$ This is suggestive of the fact that the addition of an extra round of elections, while often justified on the grounds of saving on election costs and boosting turnout, actually has a hidden cost in terms of poorer quality elections given that ROs are managing two different sets of processes and votes over the same period of time. Given that local elections have had many difficulties, this would seem to be a potentially important finding. There are clear examples to illustrate this across the United Kingdom. In 2014, there were numerous problems in Tower Hamlets council in London, which appeared, in part, to be due to having to administer the count for several concurrent elections for the European parliament, the council, and for local mayor (BBC, 2014). ${ }^{18}$ Similar complaints have been made in Northern Ireland (Electoral Commission, 2011).

Contrary to Hypothesis 3, which suggests that higher levels of performance would be evident where only one constituency is being administered, running multiple constituencies has a positive relationship with the integrity index which is

\footnotetext{
17 Tested for because of the relatively small $N$ involved in this study.

18 A case of electoral fraud in these elections was also upheld against the elected Mayor, who was removed from office by an election court (BBC, 2015).
} 
statistically significant at the $P<0.01$ level. This underlines the bivariate finding. However, it is unclear why this might be the case. One possible reason might be that extra resources, for instance, in terms of higher numbers of staff, are involved in the election leading to such a positive effect. This idea is supported by the fact that ROs with responsibilities for multiple constituencies were better financially resourced. They spent on average $£ 730,943$ on election administration in 2010-11, more than double the $£ 344,320$ for ROs who administered only one constituency. ${ }^{19}$ Indeed, it might be that the results from both electoral structural variables can be explained by resources or the relative lack of them. While ROs running concurrent elections also typically spent more than those not doing so, the magnitude of difference was much less, having only around $44 \%$ more resources, whereas those running multiple constituencies had typically more than double the resources available to those only administering one constituency. ${ }^{20}$ Staffing issues, the key expenditure cost in electoral administration, are typically cited in such cases (Electoral Commission, 2011; BBC, 2014).

Model 2 tests hypotheses relating to local authority organization, partisanship, and resources expended on electoral administration. The directionality of findings from Hypotheses 2 and 3 in model 1 are retained in this second model, albeit at a weaker level of significance for multiple constituencies. Examining the type of local authority administering the elections, Hypothesis 4 can essentially be rejected. One type of local authority, Scottish unitary councils, has a statistically significant relationship with election quality, albeit this is weak at the $P<0.1$ level. This is likely to be explained by slightly different electoral arrangements in Scotland than elsewhere in Britain (Clark, 2015). The other types of local authority have no independent statistically significant relationship to the dependent variable. Similarly, partisanship has no independent statistically significant effect on election quality in model 2 permitting the rejection of Hypothesis 5. Importantly however, the level of resources spent on electoral administration per elector does permit the acceptance of Hypothesis 6. In other words, the better resourced electoral administration is, the more likely it is that higher quality elections will be the result. This is statistically significant at the $P<0.05$ level.

Model 3 includes the socio-economic variables from 'hard-to-reach' groups, and retains the electoral structure variables, EA spending per elector, and partisanship. There is some evidence to support Hypothesis 7 regarding hard-to-reach populations, although this is somewhat contradictory and tentative. The proportion of long-term unemployed has a negative relationship, significant at the $P<0.1$ level,

\footnotetext{
19 Comparison of means shows this difference is statistically significant at the $P<0.01$ level. $\eta$ Measures of association are mid-range strength at 0.574 and 0.329 , respectively.

${ }^{20}$ ROs running concurrent contests spent on average $£ 620,363$, while those running only the parliamentary contest spent $£ 430,182$. The difference is statistically significant at the $P<0.01$ level, but the $\eta$ and $\eta^{2}$ measures are weak at 0.282 and 0.080 , respectively. An interaction term of the number of constituencies run and amount spent was tested for in models 2 and 3 in a previous version of this paper, not shown here because of space limitations. In neither model did it attain statistical significance.
} 
while the proportion of those who have never worked has a positive relationship, significant at the $P<0.05$ level. Importantly, students and internal migration appear to have no statistically significant effects, nor, separately, does partisanship. However, the electoral structure variables of multiple constituencies and concurrent elections both achieve significance, at the $P<0.01$ level for multiple constituencies and $P<0.05$ level for concurrent elections. Both maintain the same directionality as under model 1, with multiple constituencies associated with better performance on the electoral administration index and concurrent elections leading to lower performance. Notably, model 3 also highlights the importance of spending on election administration per elector in improving election quality. In this model, a positive relationship is statistically significant at the $P<0.01$ level. Hypothesis 6 therefore receives support in model 3.

While the effect of EA spending is not overly strong, this is, nevertheless, an important finding, pointing to the assertion made by many scholars and election administrators that lower levels of spending may harm election quality (Hall and Tokaji, 2007; Gerken, 2009; Wilks-Heeg, 2009; Montjoy, 2010; Watson, 2011; James, 2013; Clark, 2014a). ${ }^{21}$ Given that the major part of election administration spending is on staffing (Alvarez and Hall, 2006; Montjoy, 2010; Clark, 2014b), this may also underline further, albeit indirectly, the points made above regarding staffing, multiple constituencies, and concurrent elections.

\section{Conclusion}

This article has provided an important exploratory analysis of some of the factors which may drive election quality and integrity in an advanced democracy. This has been based on a rare multivariate examination of the performance of election administration in a national parliamentary election. The findings have established that, under certain conditions, a number of factors may have an impact on election quality in advanced democracies. What follows from this if higher quality elections are to be achieved? Several possible issues need to be addressed by practitioners and policymakers. First, there needs to be a debate about running concurrent elections. The evidence here suggests that holding different types of elections at the same time leads to lower quality election administration across Britain. While there may well be benefits in terms of higher turnout for 'second-order' elections when holding them together with other contests, there are also clearly costs involved in terms of election quality. Higher turnout is somewhat beyond the point if people have problems casting their votes, or having them counted. What should take priority is an open question, but the difficulties of concurrent elections need to be acknowledged, both in Britain and elsewhere. Indeed, it is interesting to note that one jurisdiction in

\footnotetext{
${ }^{21}$ Spending was also tested as the total amount spent on EA expressed as $£^{\prime} 000$ s. This was also statistically significant in model 3 at the $P<0.05$ level in both models 2 and 3 . The results are not shown due to space limitations.
} 
Britain, Scotland, has already moved away from holding local and Scottish parliamentary elections together because of administrative difficulties in 2007.

Second, there is clearly variation in election quality across different local authorities throughout Britain. Understanding what local authority electoral departments are doing best, what is driving that, whether organizationally within the council or externally, and whether or not practice might be improved upon as a consequence is crucial. The Electoral Commission's performance standards are useful, and similar ideas are being adopted for election monitoring more generally elsewhere, but more can be done with them. As an example, the index created here provides an additional tool for practitioners to understand this variation, and what is driving it.

Third, the findings highlight the importance of resources in electoral administration. In short, resources drive capacity, and the more spent on election administration, the higher the level of performance in election management is likely to be. Protecting resources for running elections during the current austerity squeeze may be challenging. Yet, for electoral integrity it is crucial. Spending levels should be maintained, and where local authorities are under-resourced in this area, efforts should be made to improve them with support from national-level government and other relevant stakeholders. While increases in election quality may only be incremental, nevertheless, the additional staff, training, or other changes to practices and procedures that such funding may secure could go a long way to avoiding future problems at the polls.

These findings are also important for comparative scholars of electoral integrity. Indeed, the importance of this research lies in the fact that this exploratory analysis has begun to unravel the drivers and determinants of electoral integrity in advanced democracies. In other words, it is a step towards a greater understanding of what works in electoral administration and, ultimately, to improved electoral processes for voters, parties, and candidates. Further data collection and research across a range of different settings is naturally required in order to test these findings elsewhere.

\section{Acknowledgements}

The author is grateful to the participants on electoral integrity panels for the feedback received at ECPR General Conference and the EPOP Conference, both in 2014. The author is also grateful to the Department of Political Science at LUISS Guido Carli, Rome, for a congenial intellectual home while completing an early version of this paper while on sabbatical. The author would specifically like to thank Leonardo Morlino and Sergio Fabbrini for their support while there, and Marta Regalia and Mattia Guidi for comments on a draft presented to the LUISS School of Government. The author is also grateful to three anonymous reviewers and the editors for their helpful comments on previous versions. The usual disclaimer applies. 


\section{References}

ACE Electoral Knowledge Network (n.d.), 'Overview of electoral integrity'. Retrieved 16 March 2012 from http://aceproject.org/ace-en/topics/ei/ei10.

Alvarez, R.M. and T.E. Hall (2006), 'Controlling democracy: the principal-agent problems in election administration', Policy Studies Journal 34(4): 491-510.

Andersen, R. (2004), 'Regression models for ordinal data', in M.S. Lewis-Beck, A. Bryman and T.F. Liao (eds). The Sage Encyclopaedia of Social Science Research, Vol. 3 London: Sage, pp. 941-942.

Andrews, R. and G. Boyne (2011), 'Corporate capacity and public service performance', Public Administration 89(3): 894-908.

Andrews, R., G.A. Boyne, J. Law and R.M. Walker (2005), 'External constraints on local service standards: the case of comprehensive performance assessment in English local government', Public Administration 83(3): 639-656.

Atkeson, L.R. and K.L. Saunders (2007), 'The effect of election administration on voter confidence: a local matter?', PS: Political Science and Politics 40(4): 655-660.

BBC (2014), 'Tower hamlets count reviewed by electoral commission', BBC News. Retrieved 30 May 2014 from http://www.bbc.co.uk/news/uk-england-london-27585346.

BBC (2015), 'Tower hamlets election fraud mayor Lutfur Rahman removed from office', BBC News. Retrieved 9 June 2015 from http://www.bbc.co.uk/news/uk-england-london-32428648.

Birch, S. (2011), Electoral Malpractice, Oxford: Oxford University Press.

Breunig, C. and A. Goerres (2011), 'Searching for electoral irregularities in an established democracy: applying Benford's law to Bundestag elections in unified Germany', Electoral Studies 30(3): 534-545.

Clark, A. (2012), 'Party organisation and concurrent multi-level local campaigning: the 2007 Scottish elections under MMP and STV', Party Politics 18(4): 603-622.

- (2014a), 'Investing in electoral management', in P. Norris, R. Frank and F.M. i Coma (eds) Advancing Electoral Integrity, New York: Oxford University Press, pp. 165-188.

- (2014b), 'Funding capacity in electoral democracy: insights from electoral administration'. Paper presented to PSA Annual Conference, 14-16 April, Manchester.

- (2015), 'Public administration and the integrity of the electoral process in British elections', Public Administration 93(1): 86-102.

Clark, A. and T.S. James (2015), 'The unsung heroes of electoral democracy: poll workers and electoral integrity in Britain'. Paper presented to Pre-APSA Electoral Integrity Workshop, 2 September, San Francisco, CA.

Coma, F.M.I. and C. van Ham (2015), 'Can experts judge elections? Testing the validity of expert judgements for measuring electoral integrity', European Journal of Political Research 54(2): 305-325.

Dahlberg, S. and S. Holmberg (2014), 'Democracy and bureaucracy: how their quality matters for popular satisfaction', West European Politics 37(3): 515-537.

Denver, D., R. Johns and C. Carman (2009), 'Rejected ballot papers in the 2007 Scottish parliament election: the voters' perspective', British Politics 4(1): 3-21.

Electoral Commission (2009a), Performance Standards for Returning Officers in Great Britain, London: Electoral Commission.

Electoral Commission (2009b), Report on Performance Standards for Returning Officers in Great Britain: European Parliamentary Elections 2009, London: Electoral Commission.

Electoral Commission (2010a), Report on Performance Standards for (Acting) Returning Officers in Great Britain: UK General Election 2010, London: Electoral Commission.

Electoral Commission (2010b), The Completeness and Accuracy of Electoral Registers in Great Britain, London: Electoral Commission.

Electoral Commission (2011), Report on the Northern Ireland Assembly Election on 5 May 2011, Belfast: Electoral Commission.

Elklit, J. (1999), 'Electoral institutional change and democratization: you can lead a horse to water, but you can't make it drink', Democratization 6(4): 28-51.

Elklit, J. and A. Reynolds (2001), 'Analysing the impact of election administration on democratic politics', Representation 38(1): 3-10. 
Elklit, J. and A. Reynolds (2005), 'A framework for the systematic study of election quality', Democratization 12(2): 147-162.

Evans, M. (2012), 'Beyond the integrity paradox - towards "Good Enough" governance', Policy Studies 33(1): 97-113.

Gerken, H.K. (2009), The Democracy Index: Why Our Election System is Failing and How to Fix It, Princeton, NJ: Princeton University Press.

Hale, K. and C.D. Slaton (2008), 'Building capacity in electoral administration: local responses to complexity and interdependence', Public Administration Review 68(5): 839-849.

Hall, T. and D. Tokaji (2007), 'Money for data: funding the oldest unfunded mandate'. Equal Vote Blog, Election Law at Moritz. Retrieved 8 May 2013 from http://moritzlaw.osu.edu/blogs/tokaji/ 2007_06_01_equalvote_archive.html.

Hall, T., J.Q. Monson and K.D. Patterson (2007), 'Poll workers and the vitality of democracy: an early assessment', PS: Political Science and Politics 40(4): 647-654.

Hasen, R.L. (2012), The Voting Wars: From Florida 2000 to the Next Election Meltdown, New Haven, CT: Yale University Press.

Heckman, J., C. Heinrich and J. Smith (1997), 'Assessing the performance of performance standards in public bureaucracies', American Economic Review 87(2): 389-395.

Heinrich, C.J. (2002), 'Outcomes-based performance management in the public sector: implications for government effectiveness', Public Administration Review 62(6): 712-725.

James, T.S. (2010), 'Electoral modernisation or elite statecraft: electoral administration in the United Kingdom 1997-2007', British Politics 5(2): 179-201.

- (2012), Elite Statecraft and Election Administration: Bending the Rules of the Game?, Basingstoke: Palgrave.

- (2013), 'Fixing failures of UK electoral management', Electoral Studies 32(4): 597-608.

- (2014), 'The spill over and displacement effects of implementing elections administration reforms: introducing individual electoral registration in Britain', Parliamentary Affairs 67(2): 281-305.

Kimball, D.C. and M. Kropf (2006), 'The street-level bureaucrats of elections: selection methods for local election officials', Review of Policy Research 23(6): 1257-1268.

Minnite, L.C. (2010), The Myth of Voter Fraud, Ithaca: Cornell University Press.

Montjoy, R.S. (2008), 'The public administration of elections', Public Administration Review 68(5): $788-799$.

- (2010), 'The changing nature ... and costs ... of electoral administration', Public Administration Review 70(6): 867-875.

Morlino, L. (2004), 'What is a good democracy?', Democratization 11(5): 10-32.

Mozaffar, S. and A. Schedler (2002), 'The comparative study of electoral governance: an introduction', International Political Science Review 23(1): 5-27.

Murphy, P., K. Greenhalgh and M. Jones (2011), 'Comprehensive performance assessment and public services improvement in England? A case study of the benefits administration service in local government', Local Government Studies 37(6): 579-599.

Norris, P. (2013a), 'The new research agenda studying electoral integrity', Electoral Studies 32(4): $563-575$.

— (2013b), 'Does the world agree about standards of electoral integrity? Evidence for the diffusion of global norms', Electoral Studies 32(4): 576-588.

- (2014), Why Electoral Integrity Matters, Cambridge: Cambridge University Press.

- (2015), Why Elections Fail, Cambridge: Cambridge University Press.

Norris, P., R. Frank and F. Martinez i Coma (eds) (2014), Advancing Electoral Integrity, New York: Oxford University Press.

Organisation for Security and Co-operation in Europe/Office for Democratic Institutions and Human Rights (OSCE/ODIHR) (2008), Italy Parliamentary Elections 13-14 April 2008: OSCE/ODIHR Election Assessment Mission Report, Warsaw: OSCE.

OSCE/ODIHR (2010), United Kingdom of Great Britain and Northern Ireland General Election 6 May 2010: Election Assessment Mission Report, Warsaw: OSCE/ODHIR. 
OSCE/ODIHR (2013), The Italian Republic, Early Parliamentary Elections 24-25 February 2013: OSCE/ODIHR Needs Assessment Mission Report 7-10 January 2013, Warsaw: OSCE.

OSCE/ODIHR (2015), Canada Parliamentary Elections 19 October 2015: OSCE/ODIHR Needs Assessment Mission Report 19-22 May 2015, Warsaw: OSCE.

Pastor, R.A. (1999), 'The role of electoral administration in democratic transitions: implications for policy and research', Democratization 6(4): 1-27.

Pennings, P., H. Keman and J. Kleinnijenhuis (1999), Doing Research in Political Science, London: Sage.

Perrow, C. (1999), Normal Accidents: Living with High-Risk Technologies, Princeton, NJ: Princeton University Press.

Rosenblatt, G., P. Thompson and D. Tiberti (2012), 'The quality of electoral registers in Great Britain and the future of electoral registration', Parliamentary Affairs 65(4): 861-876.

Schaffer, F.C. (2008), The Hidden Costs of Clean Election Reform, Ithaca, NY: Cornell University Press.

Snelling, C.J. (2015), 'Young people and electoral registration in the UK: examining local activities to maximise youth registration', Parliamentary Affairs, doi:10.1093/pa/gsv054.

Sobolewska, M., S. Wilks-Heeg, E. Hill and M. Borkowska (2015), Understanding Electoral Fraud Vulnerability in Pakistani and Bangladeshi Origin Communities in England: A View of Local Political Activists, Manchester: Universities of Manchester and Liverpool.

Steenbergen, M.R. and G. Marks (2007), 'Evaluating expert judgements', European Journal of Political Research 46(3): 347-366.

Stewart, J. (2006), 'A banana republic? The investigation into electoral fraud by the Birmingham election court', Parliamentary Affairs 59(4): 654-667.

Vickery, C. and E. Shein (2012), Assessing Electoral Fraud in New Democracies: Refining the Vocabulary, Washington, DC: IFES.

Watson, J. (2011), 'Public confidence in elections', in D. Wring, R. Mortimore and S. Atkinson (eds) Political Communication in Britain: The Leader Debates, The Campaign and the Media in the 2010 General Election, Basingstoke: Palgrave, pp. 126-143.

Wilks-Heeg, S. (2009), 'Treating voters as an afterthought? The legacies of a decade of electoral modernisation in the United Kingdom', Political Quarterly 80(1): 101-110.

Wise, C.R. (2001), 'Election administration in crisis: an early look at lessons from Bush versus Gore', Public Administration Review 61(2): 131-139. 